\title{
Intermédialités
}

Histoire et théorie des arts, des lettres et des techniques

Intermediality

History and Theory of the Arts, Literature and Technologies

\section{Making Memories: Time and Responsibility in Intermedial Metatheatre}

\section{Lowell Gasoi}

Numéro 33, printemps 2019

restituer (le temps)

rendering (time)

URI : https://id.erudit.org/iderudit/1065019ar

DOI : https://doi.org/10.7202/1065019ar

Aller au sommaire du numéro

Éditeur(s)

Revue intermédialités

ISSN

1920-3136 (numérique)

Découvrir la revue

Citer cet article

Gasoi, L. (2019). Making Memories: Time and Responsibility in Intermedial Metatheatre. Intermédialités / Intermediality, (33).

https://doi.org/10.7202/1065019ar
Résumé de l'article

Il est peut-être admis qu'une performance peut être captée et rediffusée, mais le rapport existant entre cette performance enregistrée, la mémoire de l'acte performé et l'événement direct est bien moins évident. De même que la pratique d’un théâtre intermédial offre une perspective spécifique sur ce rapport, prendre conscience de la métathéâtralité permet de mettre en évidence les liens existant entre mémoire, technologie et performance. Dans cet article, je soutiens que le métathéâtre intermédial, au même titre que mon propre travail de metteur en scène, vidéaste et performeur vidéo lors de la production en 2014 de Never Swim Alone - une pièce de Daniel MacIvor —, est un bon exemple de recherche-création pouvant éclairer ces questions de façon concrète et expérientielle. À partir de la notion de média performatif développée par Sarah Kember et Joanna Zylinska et du concept de travail de mémoire pensé par Annette Kuhn, je propose une réflexion sur la matérialité, le temps et la reconstitution médiatique de la mémoire, captés par des technologies telles que les caméras et les équipements de prise de son, et dans des espaces construits comme les studios et les salles de répétition, représentés par des logiciels cartographiant les projections et par des projecteurs numériques installés dans l'espace théâtral. Tous ces éléments sont intégrés à un réseau d'acteurs et de techniques qui rendent compte des pratiques ayant cours dans les créations du théâtre intermédial. Cette recherche est-elle capable d'éclaircir les idées d'authenticité et de liveness quand sont réactivées des mémoires par la présence des acteurs sur scène, et ce, devant une audience ? Et qu'en est-il de notre responsabilité à l'égard de la représentation numérique et des performeurs, lorsque nous réunissons ces mémoires et ces moments ? De quelle manière le réseau de technologies et d'agents investis dans la création et la présentation de pièces de théâtre intermédial comprend-il et respecte-t-il la lifeness d'une mémoire reconstituée médiatiquement?
Ce document est protégé par la loi sur le droit d'auteur. L’utilisation des services d’Érudit (y compris la reproduction) est assujettie à sa politique d'utilisation que vous pouvez consulter en ligne.

https://apropos.erudit.org/fr/usagers/politique-dutilisation/ 


\title{
Making Memories: Time and Responsibility in Intermedial Metatheatre
}

\author{
LOWEll Gasol
}

\section{INTRODUCTION: MAKING MEMORIES}

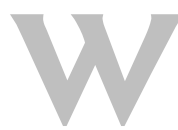

hile live theatre remains a bastion of co-presence and co-temporality among the network of audience, players, and theatrical technologies, there is little doubt that the practice and consumption of performances continues to morph under the influence of technologized presentation techniques, particularly the use of projections and pre-recorded performance elements in concert with the live event. As a theatre-maker and consumer, I note the near-ubiquitous presence of the "video designer" position in the playbill of shows I attend. Theatre is very often explored as a temporally problematized experience, as in the liminal theories of Victor Turner, ${ }^{\mathrm{I}}$ yet we can and should examine the increasing intermediality of theatrical practice in light of such temporality. The practice of intermedial theatre, defined by Freda Chapple and Chiel Kattenbelt as "the incorporation of digital technology into theatre practice, and the presence of other media within theatre productions," ${ }^{2}$ challenges the primacy of the live by incorporating digitally mediated representations, be they elements of set, costume, still images, and commentary slides, all the way to entirely digital characters. Steve Dixon calls these practices "digital performance," though he expands his categorization to include performances that cannot be considered to have traditionally "live" connotations such as CD-ROMS, multiplayer online games, and

${ }^{\mathrm{I}}$ Victor Witter Turner, From Ritual to Theatre: The Human Seriousness of Play, New York, Performing Arts Journal Publications, 1982.

${ }^{2}$ Freda Chapple and Chiel Kattenbelt, Intermediality in Theatre and Performance, Amsterdam, Rodopi, 2006, p. II. 
the like. ${ }^{3}$ By constraining my notion of intermedial theatre, I can consider these mediations in a context that helps to frame them as technologically extended memories of past performance, re-activated in the live moment, alongside live performers who must struggle with their relationship to the intermedial. Bryan Reynolds, in his work on intermedial theatre, offers the key thought that the practice blends forms in such a way that "may more accurately reflect the way people normally engage the world." 4 Theatre has always embraced a mediated nature, the proscenium arch itself presenting a framed reality that, despite engagements with stark realism, never quite forgets its roots in ritual and ceremony, in presenting a memory of moments made alive again by performers both present and, in the case of digitally reprojected performances, absent.

As Mark Hobart suggests in his work on Balinese televised theatre, the issues raised once the privileged authenticity of live performance is challenged by technologies of recording and re-presentation (or broadcast) have "transformed the theatre,"s and continue to do so. In an argument reminiscent of Philip Auslander's in Liveness, ${ }^{6}$ Hobart notes the tendency to fetishize the "live" performance as something lost in the push towards mediatization and the digital. Where this paper diverges from Hobart is in considering the integration of recording and broadcast (or projection) within the theatrical moment itself, and how particular post-dramatic forms of metatheatre can be a productive means to think about intermediality and memory, performances in time.

The term metatheatre, originally coined by Lionel Abel, is used here to denote a play that is aware of its own theatrical nature, with characters that acknowledge the heightened, mediated world that they are co-creating with their audience. ${ }^{7}$ I approach

\footnotetext{
3 Steve Dixon, Digital Performance: A History of New Media in Theater, Dance, Performance Art, and Installation, $\mathrm{I}^{\text {st }}$ edition, Cambridge, Massachusetts, MIT Press, 2007, p. 3 .

4 Bryan Reynolds, Intermedial Theater: Performance Philosophy, Transversal Poetics, and the Future of Affect, London, Palgrave Macmillan, coll. "Palgrave Studies in Performance and Technology," 2017, p. 7.

s Mark Hobart, "Live or Dead? Televised Theatre and Its Audiences in Bali," in Felicia Chan, Angelina Karpovich, and Xin Zhang (eds.), Genre in Asian Film and Television: New Approaches, London, Palgrave Macmillan, 20II, p. 13-I4.

${ }^{6}$ Philip Auslander, Liveness: Performance in a Mediatized Culture, $2^{\text {nd }}$ edition, London, Routledge, 2008.

7 Lionel Abel, Tragedy and Metatheatre: Essays on Dramatic Form, New York, Holmes \& Meier, 2003.
} 
the notion of metatheatre in a similar manner to Mary Ann Frese Witt, who suggests that much scholarship has been focused on defining metatheatre as an object rather than interrogating what it does, and whether it can, in fact, "perform significant functions in dramatic innovation." 8 My examination differs in that, rather than setting metatheatre against some historic and aesthetic movements, I suggest it can help to understand and reflect the practices of technologization and digital memory presentation as part of the mediated theatrical moment.

\section{A NOTE ON RESEARCH-CREATION}

94

Hobart and I share a belief in the importance of an ethnographic lens through which to study this transformation of reality and of the theatre, and I take that challenge further by engaging in practice-led research, which incorporates the entire process of production and presentation of intermedial and metatheatrical work. Direct experience and observation of the work of creation and presentation illuminates the questions posed in a media environment defined increasingly by communion with multiple screens, even in the hallowed halls of the traditionally live theatre. How are we making mediated memories of the past and integrating them into the present theatrical moment?

I am drawing on research-creation methodology through the production and presentation of an intermedial theatre performance: Daniel MacIvor's 1992 play Never Swim Alone presented in the fall of 2014, in which I chose to pre-record and project one of the characters in the play, the Referee, making her present only as a digital memory for the other two live players. This allowed me to closely interrogate the processes of capturing, rehearsing with actors, and re-presenting digitally mediated memory in relation to the live moment, witnessed by a collective audience. Using the insights of the actors and my own experience as director and video designer, side-by-side with theoretical discussions of intermediality and metatheatre as it relates to questions of memory, liveness, and lifeness, I will inquire into the definition of and responsibility to these "new species" 9 of performances and suggest that we continue to use the theatrical moment to examine the ethical questions around mediated performances, liveness, and our interactions with memory and temporality.

\footnotetext{
${ }^{8}$ Mary Ann Frese Witt, Metatheater and Modernity: Baroque and Neobaroque, Madison, New Jersey, Fairleigh Dickinson University Press, 2014, p. 9.

9 David Z. Saltz, "Live Media: Interactive Technology and Theatre," Theatre Topics, vol. II, no. 2, September 200I, p. I07-30, https://muse.jhu.edu/article/35249/pdf (accessed I8 May, 20I9).
} 
Never Swim Alone is an example of MacIvor's late 1980s and early I990s oeuvre (including works like Wild Abandon, 1990; See Bob Run, 1987; House, 1992, and This Is a Play, 1992) that exhibit a unique metatheatrical awareness of their own mediated nature. As noted by critic and scholar Carol Bolt, who writes in the preface to the two-play collection that includes Never Swim Alone, MacIvor creates theatrically aware and needy characters who "seem to believe that their audience will actually help" "Io to address their problems. In MacIvor's metatheatrical worlds, a fluid sense of time and memory invites the use of intermedial techniques like projections, although to my knowledge, no one has previously taken that to the level of digitally mediating an entire character as with the Referee in this play. My experiences, and those of my research collaborators Paula Jean Hixson (as the recorded and projected Referee), Aaron George (as Frank), and Alex Goldrich (as Bill), will provide an ethnographic frame for this exploration, building on experiential narratives that coconstitute a world of human agency and the slipperiness of what Bernard Stiegler called "organized inorganic matter," II the digitally mediated memory that is the projected character in this play.

Research-creation as a method in this investigation impacts both the development of questions and the presentation of the research findings. In Brad Haseman's "Manifesto for Performative Research" this kind of practice-led work is acknowledged as deriving from "an enthusiasm of practice." 12 Rather than approaching the question of how the digital impacts the creation and presentation of theatre, I identified a practice that I wanted to explore-one that seems increasingly relevant to current theatrical production - and gathered curious collaborators to see what such a process of doing might reveal. Presenting the work as a play was a necessary step in the research, "reporting research through the outcomes and material forms of practice" and challenging traditional forms of knowledge production. ${ }^{13}$ As Owen Chapman and Kim Sawchuk argue in their discussion of this kind of work, it is " a form of critical intervention that speaks to the media experiences and modes of

Io Carol Bolt, "Preface," Never Swim Alone EG This Is a Play: Two Plays, I $^{\text {st }}$ edition, Toronto, Playwrights Canada Press, 1993, p. 8.

"I Bernard Stiegler, Technics and Time: The Fault of Epimetheus, Stanford, California, Stanford University Press, 1998.

${ }^{12}$ Brad Haseman, "A Manifesto for Performative Research," Media International Australia Incorporating Culture and Policy, vol. II8, no. I, 2006, p. Ioo, https://journals.sagepub.com/doi/pdf/Io.II77/1329878Xo6II80oII3 (accessed I8 May 2019).

${ }^{13}$ Ibid., p. IoI. 
knowing by students and scholars in this moment." ${ }^{14}$ This work falls under these authors' loose topology of practice-led research as an example of “creation-asresearch," a mode of knowledge-generation where the questions emerge from practice and the presentation of the output is "both a tracing-out and culminating expression of the research process." 'Is As such, this paper exists as part of that performative backand-forth between theory and practice that must acknowledge its own limitations as one iteration, perhaps a summative one for the moment, of an ongoing process of knowledge-making. ${ }^{16}$

\section{Intermediality, Performative Media, And Memory Work}

Reynolds suggests that intermedial theatre "powerfully demands responsive awareness of the numerous and force-multiplying variables at work in every performance moment." ${ }^{17}$ Awareness of theatricality is a fundamentally metatheatrical concept, and while Reynolds is likely referring to an analysis of the theatrical taking place from an outside, academic context, and not necessarily related directly to the technological mediation of intermediality suggested by Chapple and Kattenbelt, my work argues for an intimate relationship to the performance and its mediations that embraces metatheatricality as a foundational part of intermediality.

The technologization of liveness and the penetration of screens into every corner of our existence forces continuing encounters between live performance and digital mediation. In this context, theatre remains important as its incorporation of intermedial techniques invites us to examine our awareness of the theatrical nature being represented, and our responsibility to connect to the elements of the performance that are exteriorized into digitally represented memory. As we continue to struggle with a political and cultural landscape that is cynically selfaware and reflexive to a point of narcissism, metatheatricality is becoming a default vision of theatricality, reflecting or perhaps refracting reality itself.

${ }^{14}$ Owen B. Chapman and Kim Sawchuk, "Research-Creation: Intervention, Analysis and 'Family Resemblances'," Canadian Journal of Communication, vol.37, no. I, 2012, p. 7 , https://www.cjc-online.ca/index.php/journal/article/view/2489/2766 (accessed I8 May 2019).

is Ibid., p. 20.

${ }^{16}$ Ibid., p. 20-2I.

${ }_{17}$ Reynolds, 20I7, p. 7. 
I will engage here with two closely connected frameworks: performative media, as understood by Sarah Kember and Joanna Zylinska in their book Life after New Media: Mediation as a Vital Process, ${ }^{18}$ and Annette Kuhn's memory work. ${ }^{19}$ Kuhn's understanding of memory as a process that involves a relationship with the material and increasingly digital representations of memories is vital to an exploration of captured and re-projected performance as it unfolds in the public space of the theatre. Kember and Zylinska offer an equally important perspective on these questions by breaking down the binary of live and mediated and suggesting that media can exhibit "lifeness," a quality that goes beyond media as representation, offering instead a performative, "intra-active" relationship to reality, ${ }^{20}$ and one that requires a sense of responsibility. I further relate to their approach as both Kember and Zylinksa are practitioners (in the realm of photography and new media) as well as scholars, and their work foregrounds experiential knowledge and memories, drawn from practice-led research.

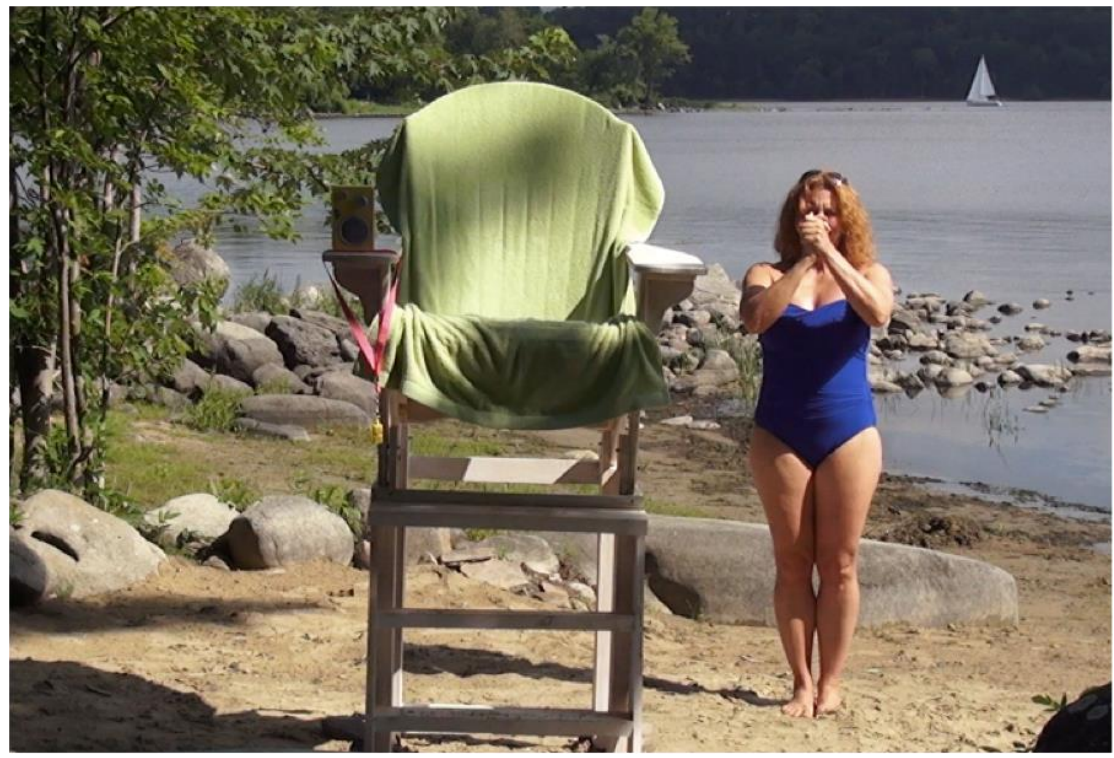

Fig. I. Still from a video recording of the performance of Never Swim Alone (Daniel MacIvor, I99I), directed by Lowell Gasoi, July 20I4. Courtesy of the author.

${ }^{18}$ Sarah Kember and Joanna Zylinska, Life after New Media: Mediation as a Vital Process, Cambridge, Massachusetts, MIT Press, 2012.

${ }^{19}$ Annette Kuhn, "Memory Texts and Memory Work: Performances of Memory in and with Visual Media,” Memory Studies, vol. 3, no. 4, 20I0, p. 298-313.

${ }^{20}$ Kember and Zylinska, 2oI2, p. 64. 
To examine questions around intermediality and the nature of creating this Referee character, I engaged Paula to perform the role on camera. I video-recorded her performance, on an actual beach, in the summer of 2014 (see Fig. I). We worked together to build the scenes, reactions, moments of intervention, and monologues that would be projected onto screens alongside the two live actors in the play. An assistant and I read the cue lines for Paula, and since the play does not feature extensive direct dialogue between the Referee and the two men, it was possible to build Paula's character as a protention, ${ }^{2 \mathrm{I}}$ a series of potentialities that would then be deployed alongside the live characters. What we created together was not only a technologically mediated memory, but an example of what I would consider performative media.

Kember and Zylinska's reading of performative media suggests that our relationship with memory as it is mediated by technologies of recording and presentation like the video cameras and projectors used in my theatrical production, create "media events with a difference." 22 These are not simply representations of performances, nor memories of action, but, in the vein of J. L. Austin's performative utterances, ${ }^{23}$ they are co-creations that have a "lifeness," ${ }^{24}$ an agency, and unanticipated potentiality of their own. Kember and Zylinska point to the example of the "event" of turning on the Large Hadron Collider at CERN to try to discover the elusive Higgs-Boson, dubbed the "God particle," a building block for all matter in the universe. The authors argue that the boson itself will never be seen, it cannot be perceived by human eyes, but its existence will be co-created through mediations: on computer monitors, in the media reports of those journalists present for the moment, and in the performances of joy and rapture on the faces of the scientists when the right series of numbers appear. ${ }^{25}$ These representations of the boson are performative media, a mediation that continually co-creates a social reality, just as the projected Referee co-creates the reality of the play for Frank and Bill.

${ }^{21}$ Edmund Husserl, Phenomenology of Internal Time Consciousness, ed. Martin Heidegger and introduction by Calvin O. Schrag, translation by James S. Churchill, $\mathrm{I}^{\text {st }}$ edition, Ann Arbor, Michigan, Indiana University Press, 1964.

${ }^{22}$ Kember and Zylinska, 20I2, p. 4I.

${ }^{23} \mathrm{~J}$. L. Austin, How to Do Things with Words, ed. J. O. Urmson and M. Sbisà, 22 ${ }^{\text {nd }}$ edition, Cambridge, Massachusetts, Harvard University Press, 1975.

${ }^{24}$ Kember and Zylinska, 20I2, p. 3.

${ }^{25}$ Ibid., p. 55-59. 
In their understanding of actor-network theory, Kember and Zylinska write that "mediation incorporates technologies and their users, machines and their human counterparts." ${ }^{26}$ The memory of events, and especially technologically mediated memory, are not discrete objects, nor collections of ones and zeros, biological coding, nor simple configurations of light and shadow exterior to the human. This is evident especially when bringing the mediated memory into conversation with the live event of a theatrical performance. As Canadian theatremaker and scholar Jenn Stephenson argues, citing the work of theatre studies scholar Ivo Osolsobě, "In the creation of staged drama, fictional worlds of drama are populated by actual-world objects that are transformed into fictional objects. ${ }^{27}$ The actor becomes the character, just as the chair becomes the throne, or the light becomes the sun. Stephenson sees these objects as bridges linking the world of the play to the event of the performance. In other words, all of these objects are intermedial: they perform their reality of a throne, or of a memory of a drowned girl, just as they perform their liveness as chair, or as digitally mediated memory. A question demanded by this new ontology of theatrical objects and technologies is whether this intermedial duality has ever been otherwise? And what in our present moment, social, theatrical, and technological, makes this argument worth revisiting?

\section{NOTHING NEW?}

Discussions around intermediality in theatrical practice have been taking place for a long time. The theatre is an inherently multi-mediated experience, incorporating various elements - from bodies and voices in performance to visual design through sets and costumes, to sound and light. If we expand Chapple and Kattenbelt's notion of the "presence of other media," ${ }^{28}$ we can reference technologies as seemingly rudimentary as classical Greek masks (used not just as visual representations but also as vocal amplification), shadow-play, the

${ }^{26}$ Ibid., p. 68.

${ }^{27}$ Ivo Osolsobě, “Cours de Théâtristique Générale,” Études Littéraires, vol. 13, no. 3, 1980, p. 413-435, quoted in Jenn Stephenson, "Meta-Enunciative Properties of Dramatic Dialogue: A New View of Metatheatre and the Work of Slawomir Swiontek," Journal of Dramatic Theory and Criticism, vol. 21, no. I, Fall 2006, p. II9, https://journals.ku.edu/jdtc/article/view/3563/3439 (accessed I8 May 2019).

${ }^{28}$ Chapple and Kattenbelt, 2006, p. II. 
incorporation of recorded music, smoke machines, etc. In terms of projection and film effects, Greg Giesekam reminds us that this integration has a history dating back to the early 1900s in France, through I920s Germany, becoming more mainstream as Video Tape Recorders (VTRs) and then digital technologies began to emerge in the late 198 os with the work of companies like The Wooster Group ${ }^{29}$ and Quebec multimedia artist Robert Lepage. ${ }^{30} \mathrm{John}$ Willet points to the extensive use of projection technologies by Erwin Piscator, both in his famed collaborations with Bertolt Brecht and in subsequent stagings inspired by his works, of plays by Jean-Paul Sartre and Tennessee Williams. ${ }^{31}$

Is "intermedial theatre" just another way to say "theatre"? Robin Nelson, writing in the pages of this journal in 2008 , further defines intermediality as "theatre practices consciously performed 'live' before an aware audience but which overtly deploy digital media technologies." ${ }_{22}$ There are two key ideas in Nelson's quote that are of interest: an "aware audience" and the "overt" use of digital media. Why does Nelson feel the need to expand on Chapple and Kattenbelt in this way? Nelson makes an argument about the radical and political impact of such techniques as employed by Brecht, and yet this idea of overtness, the conceit of admitting the theatricality of the technological mediation is an aspect of intermedial practice that expressly connects digital mediation and metatheatricality. 33

David Saltz, who founded the Interactive Performance Laboratory at the University of Georgia, has defined a taxonomy of these intermedial forms in the theatre. His categorizations range from digital scenery and costume, through the

${ }^{29}$ A New York-based company of theatre, film, dance, and media artists founded in 1975 by Spalding Gray and Elizabeth LeCompte, http://thewoostergroup.org/blog/ (accessed May 30 2019). Known for works that incorporate live and mediatized elements.

${ }^{30}$ Greg Giesekam, Staging the Screen: The Use of Film and Video in Theatre, London, Palgrave Macmillan, coll. “Theatre \& Performance Practices,” 2007, p. 218.

${ }^{31}$ John Willett, "Erwin Piscator: New York and The Dramatic Workshop,” Performing Arts Journal, vol.2, no.3, 1978, p.3-16, https://www.jstor.org/stable/3245358?seq=I\#metadata_info_tab_contents_ (accessed I9 May 2019).

${ }^{32}$ Robin Nelson, "After Brecht: The Impact (Effects, Affects) of Intermedial Theatre," Intermédialités, «mettre en scène/directing», no. I2, Fall 2008, p. 32, https://www.erudit.org/fr/revues/im/2008-ni2-im3626/039230ar.pdf (accessed 19 May 2019).

33 Ibid. 
"commentary" of static word slides and images such as those employed by Piscator and Brecht, emotionally charged mediations that may be diegetic (existing in the imagined world of the play) or not, to what he terms "dramatic media," a digitally mediated character like the Referee that interacts with the live performers. ${ }^{34}$ Saltz argues that as such intermedial forms move towards full integration with the live performance, "a fascinating ontological question arises: is interactive media itself 'live' or not?" 35 I suggest that the qualities of intermedial theatre, the foregrounding of mediation that is often expressed by reference to Jay David Bolter and Richard Grusin's concept of hypermediacy, ${ }^{36}$ or a revealing of the processes of mediation, gives the mediated character a performative power that Saltz refers to as "a species of live performance." 37 It is this appellation, this "new species" that shifts the question of liveness to one of lifeness, and also demands an appreciation of ethical responsibility and audience "awareness" that reinvigorates these age-old debates.

\section{INTERMEDIALITY AND MACIVOR'S METATHEATRE}

Never Swim Alone is a poetic and metatheatrical rumination on male rivalry, consumerism, and the virtue of being first. In this play, two men, Frank and Bill, are trapped in an arena-like setting built from their own sense of guilt and selfrecrimination. They engage in a series of rounds of competition, measuring everything from their heights to their intimate relationships, families, stock portfolios, to the size of their penises. These rounds are presided over by the Referee, a God-like woman in a swimsuit who not only sits in judgement over their competition, but also represents the trauma of a past incident that haunts both men (see Fig. 2). As boys, they engaged in a swimming race "to the point" of a sundrenched beach and, intent upon competing to be "the first man," failed to recognize that the young girl they were trying to impress had fallen behind them and drowned..$^{8}$

34 David Z. Saltz, "Live Media: Interactive Technology and Theatre," Theatre Topics, vol. II, no. 2, September 200I, p. I07-I30, http://muse.jhu.edu/article/35249 (accessed I9 May 2019).

35 Ibid., p. 127.

${ }^{36}$ Jay David Bolter and Richard Grusin, Remediation: Understanding New Media, Cambridge, Massachusetts, MIT Press, 2003.

37 Saltz, 200I, p. 127.

${ }^{38}$ Bolt, 1993. 
Despite the recognition of MacIvor as one of Canada's great playwrights (his work is widely produced at home and abroad and he has won numerous awards, including the prestigious Siminovitch Prize for theatre in $2008^{39}$ ), the scholarship on his work is relatively thin. This gap was addressed in a recent collection of essays edited by Richie Wilcox. ${ }^{40}$ An openly gay man who is celebrated for his complex characterizations of female characters, MacIvor has produced work that has often been explored for its feminist and LGBTQI themes, for the complex and fluid gender representations in plays like $A$ Beautiful View, ${ }^{41}$ and even for his use of dance, an interesting nod towards intermediality..$^{42}$ Most of these studies focus on the themes and content of his plays, though some also touch on his striking use of metatheatricality. When I interviewed MacIvor as part of this project in 20I4, no one had as yet digitally mediated one of his characters and reflected on his work in the manner of my research-creation. MacIvor gave his support to the project in part because the structure and characters in Never Swim Alone presented that unique opportunity, and this particular play is also one of the less explored in scholarship.

Why use a play like Never Swim Alone to examine intermedial theatre? It is true that several MacIvor works propose intermedial elements in their texts, from the suggestion of slides with words on them in Wild Abandon, to the use of projected still images in Here Lies Henry - but why take that practice to the extent of mediating an entire character? One answer is suggested by the term that has come to define much of MacIvor's early work: metatheatrical. In the case of MacIvor's plays, metatheatre often manifests in ritualized language and situations that play with temporality, blurring the lines between memory and the present moment. Jenn Stephenson, who has written extensively on metatheatre and on MacIvor's work as

39 "Over a three-year cycle, the prize celebrates a professional director, playwright or designer, an acknowledged leader in the theatre whose work is transformative and influential," https://siminovitchprize.com/laureates/daniel-macivor/ (accessed 30 May 2019).

40 Richie Wilcox(ed.), Daniel MacIvor: New Essays on Canadian Theatre, vol. 5, Toronto, Playwrights Canada Press, 2015.

${ }^{41}$ Michaela Pňačeková, "Recycling Contexts: Reconstructing Gender Identities in Daniel MacIvor's A Beautiful View and Never Swim Alone," Theory and Practice in English Studies, vol. 5, no. 2, 2012, p. 57-82, https://digilib.phil.muni.cz/bitstream/handle/rr222.digilib/ı2957I/2_THEPES_5-20I22_3.pdf? sequence $=$ I (accessed I9 May 2019).

${ }^{42}$ Ray Miller, "Dance in the Plays for Daniel MacIvor," in Richie Wilcox (ed.), 2015. 
autobiographical, ${ }^{43}$ argues that theatre's unique quality of liveness that differentiates it from painting or literature, is also a constant reminder of the event as an event, a staged, fictional moment, being re-presented for an audience. ${ }^{44}$ In another sense, the theatrical world is always a memory for its performers (of rehearsals, of prior performances), while for its audience, it is a memory "with a difference," 45 something constructed and experienced communally in the mediated space of the theatre. The metatheatricality of Never Swim Alone provided a unique opportunity to consider the artifice of the theatrical world in relation to the digital mediation of memory and the materiality and temporality of the re-projected performance. The Referee-both alive in the theatrical moment, and yet a memory; both created by the two men from their shared desire to exorcise their trauma and a being of power and agency in her own right-made an ideal subject for technological representation. She is a ghost in the machine, a memory ripe for mediation.

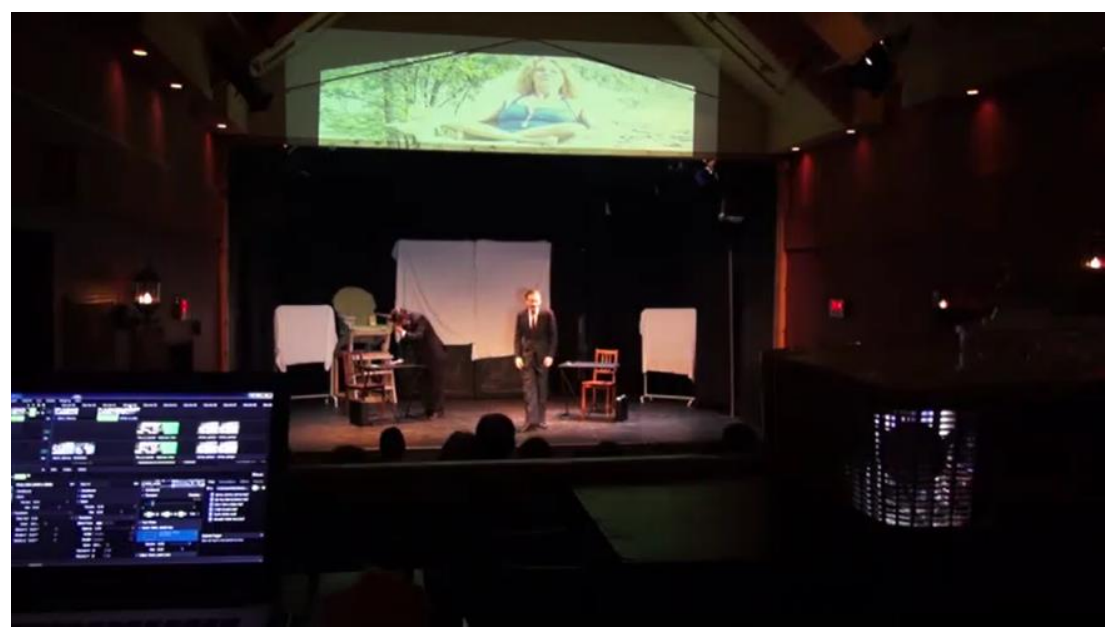

Fig. 2. Video excerpt of the performance of Never Swim Alone (Daniel MacIvor, 199I), directed by Lowell Gasoi, July 2014, http://erudit.org/media/im/Io65orgar/Io65orgarvoor.mp4, Courtesy of the author.

43 Jenn Stephenson, Performing Autobiography: Contemporary Canadian Drama, Toronto, University of Toronto Press, 2013.

44 Stephenson, 2006.

45 Kember and Zylinska, 20I2, p. 4I. 


\section{MEMORY WORK AND RESPONSIBILITY}

While I did not specifically engage with audience response as methodology in this research, part of the nature of being an actor is being an audience (literally, a listener) to the other players onstage. But what does this mean when one of those players is only ever digitally represented? Such a situation calls into question the responsibility of actors and audiences in both a theatrical and cinematic setting. Surely more is required than simply to be quiet, pay attention, laugh at the right moments, and applaud at the end?

These questions implicate the second framework I want to consider as part of this examination, that of memory work. ${ }^{46}$ Annette Kuhn theorizes this work as a productive process of memory that occurs in relationship with images, moving and still, along with other forms of technological mediation. She describes "an active practice of remembering that takes an inquiring attitude towards the past and the activity of its (re)construction through memory." 47 The two key concepts here are "active practice" and "inquiring attitude": a recognition that the ways in which the two live actors I directed, Aaron and Alex, were engaging with the mediated memory of the Referee (along with their audience) were generative, creating new connections and perspectives on that memory. Those perceptions informed their performance in the play, and ultimately, particularly in the case of a metatheatrical play, the perceptions of the audience.

Kuhn's framing is vital to an understanding of mediated memory not as an artefact, nor as an event, but as a process, or as I suggested, a memory with a difference. Her examples incorporate both the cinematic and the photographic, and with regard to the former, she writes: "Cinema, in other words, is peculiarly capable of enacting not only the very activity of remembering, but also ways of remembering that are commonly shared." ${ }^{8} 8$ What is interesting is that Kuhn does not take us into the cinema to explicate the shared moment of re-enactment that she seeks to define. The live moment of interaction with the memory text is how intermedial theatre, as a practice of re-presentation of memory, "in and with visual media," 49 as Kuhn suggests, can be examined more completely. This process can be explored not only through ethnographic analysis of the public

\footnotetext{
${ }^{46} \mathrm{Kuhn}, 2010$, p. 298-313.

47 Ibid., p. 303.

${ }^{4}$ Ibid.

49 Ibid., p. 299.
} 
perceptions of an audience, as Kuhn proposes methodologically, but also through the perceptions of performers interacting with the mediations throughout the entire process of capture, cutting, rehearsal, performance, and reflection.

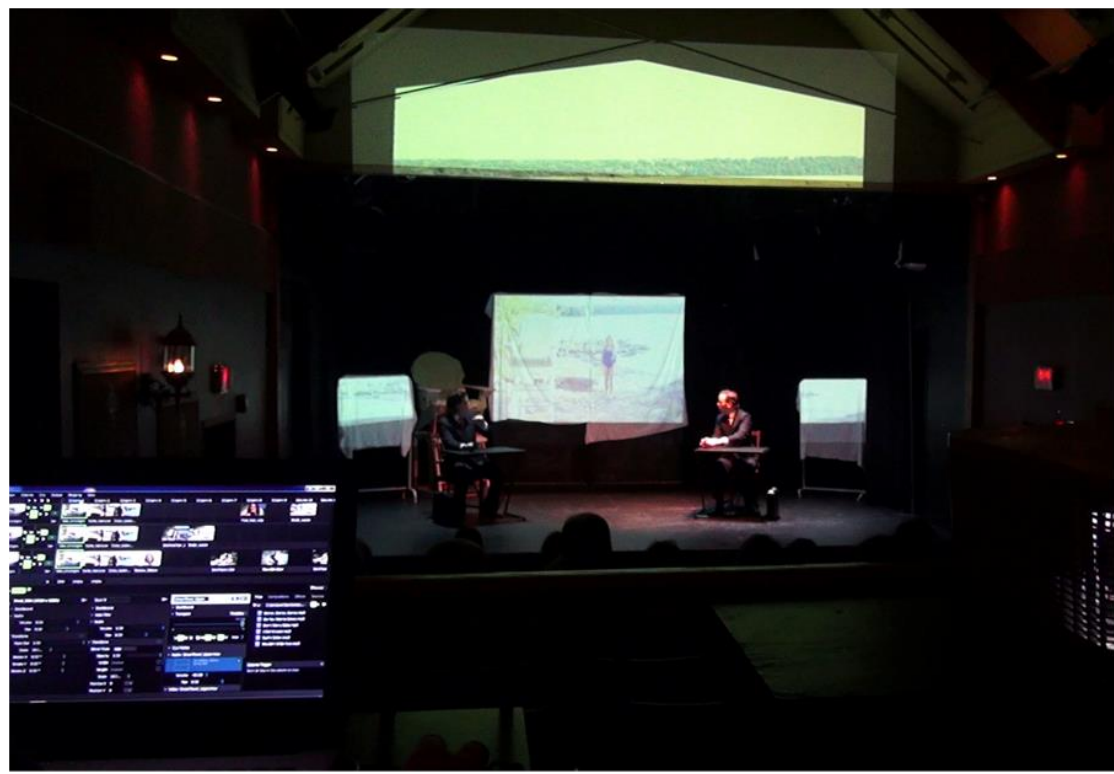

Fig. 3. Still from a video recording of the performance of Never Swim Alone (Daniel MacIvor, I99I), directed by Lowell Gasoi, July 20I4. Courtesy of the author.

\section{Responsibility And the ABSent Performer}

One thing that quickly became evident as the process of exploration unfolded with Paula and in the subsequent live rehearsals and performance with Aaron and Alex, is that we lack an understanding of the precise nature of a mediated performance: materially, spatially, temporally, and in terms of this lifeness. Rather, the lifeness of a being like the Referee exists as "the possibility of the emergence of forms always new." 50 As Dixon suggests, citing the work of Marie-Laure Ryan, ${ }^{\text {II }}$ the "virtual" performance, as in the Latin root virtualis, exists as a potential form..$^{52}$ She

so Kember and Zylinska, 2012, p. 24.

si Marie-Laure Ryan, "Cyberspace, virtuality, and the text," Cyberspace textuality: Computer technology and literary theory, Bloomington, Indiana University Press, 200o, p. 88.

52 Dixon, 2007, p. 23. 
is something beyond what Philip Auslander considers more dialectically as mediation, opposed or evolving from the temporally live. ${ }^{33}$ Kember and Zylinska borrow from Bergson, and imagine these mediations as "becoming-with" the moment of perception. ${ }^{44}$ I would argue that this suggests that the mediated form of Paula's Referee has to have a humanity, an agency, and a temporality, and interaction with her further demands ethical responsibility. How do we negotiate this question of responsibility and connection to the absent performer?

In late July 20I4, Paula and I had finished doing all the principle videography, and what remained was for me to slice up her performance, code it into a database from which I could pick out sections to project into the live space and prepare it for playing alongside the two live actors in the play. I was engaging in an open-ended discussion with Paula about how she felt and what performance techniques she was relying on to play this part on video. I asked her: "How do you feel about the video, knowing it will be presented live with the other two actors? Do you feel like you need to tell them anything?" "Not in the least," she responded. "Once the take is done, the director calls wrap, my part is complete. I have no further responsibility, no further stake in what happens. I've done all I can.”

I was fascinated by this response, which I suppose I could understand a little more readily in the usual play of filmmaking. The process, especially for large-scale Hollywood films and television shows, can be faceless and untethered. Actors, even in principle roles, are often well-aware that their work will come together in an editing room, amid countless technical and aesthetic decisions that stand between their take and what ends up before an audience. But, with this project, I somehow thought Paula might react differently. The cast of a theatrical production often feel a strong sense of responsibility to each other, to protect and support each other onstage. Was this not possible for Paula's mediated character? And what are the implications of this disconnection for me as I represent her performance through the technological mediation of computer, software, projector, and screens during the live performance?

What this moment brings to light is a question of connection, of the link between the performance of an action, the act of re-presenting its memory, and its remediation in another form. As Paula indicated in her response, the process of creating the Referee was as much mine-in the work of editing and video-mapping

\footnotetext{
53 Auslander, 2008.

54 Kember and Zylinska, 20I2, p. 4I.
} 
her onto the screens in the theatre, cutting, and choosing the moments to respond and prod Alex and Aaron during rehearsal-as it was hers in the filming process.

Citing the work of philosopher and physicist Karen Barad,55 and her concept of the "agential cut," 56 Kember and Zylinska discuss the interaction (or intra-action) between the human and the physical world. In the case of photography, the "temporary fixing(s)" 57 of reality created by the photographer, camera, and subject are just that, a momentary articulation of technology, ontology, and the human framer. To remain aware of the possible closing down of channels for new knowledge and perception through cutting is to make an ethical decision, though not one that is inherently moralistic, but rather epistemological. It is a choice that recognizes potential moments of understanding that may never come again. The work of cutting Paula's performance forced me to recognize my own place as part of that performance, alongside the technical apparatus of my software, and the memory of our intentions and desires during the creative process of filming.

The character of the Referee is a memory in the play, and the performance that is being delivered is a digitized memory of the performance co-created by Paula and myself, along with the technologies of video capture and projection. Because I was to be the "performer" who will re-present the mediation by manipulating the computer, projector, and video software during the live performance, I had to work to "not lose sight of the horizon of duration or foreclose on the creative possibility of life enabled by this horizon." ${ }^{8}$ Acting on this ethical responsibility in a physical way, I went so far as to place myself as video performer, fully visible and present in the theatre, not hidden away in a booth, but in full view of both audience and performers.

As is so often the case, the greatest moments of discovery come from moments of crisis and apparent failure. On the third night of the run of Never Swim Alone, after two flawless technical performances, the projection software crashed about midway through the play. I was able to recover quickly, but I did have to recall a couple of the Referee's lines and deliver them out loud to the actors onstage. If I could somehow mark off my presence before as a technical operator of the video equipment, now I was thrust directly into the role of live performer. This experience

\footnotetext{
5s Karen Barad, Meeting the Universe Halfway: Quantum Physics and the Entanglement of Matter and Meaning, Durham, London, Duke University Press, 2007.

${ }^{56}$ Ibid., p. 8I.

57 Ibid., p. 2 I.

${ }^{8}$ Ibid., p. 82.
} 
reminded me that behind all these mediations is human interaction, and that the representation of a memory in the theatrical moment can never be truly left in some imagined past. I could speak the lines because it was necessary to allow the play to continue and not to leave the other actors abandoned in front of an audience. But it was also possible to speak those lines and to recover because we had set up the circumstances where the movement between live and digitally mediated performance of the past was made if not easy at least natural. The presence of the projector and video performer in the audience was a metatheatrical element, allowing the digital performance to exist in a space and time that was open to flux, that was incomplete and thus in a performative relationship and not a purely representational one, with the network of agents in the theatre: audience, actors, performer, play, video, theatre space, and story space.

These relationships are reflected in the diverse experiences of the two actors, Aaron and Alex, and their perceptions of the Referee during the rehearsal and performance of the play. I quote Alex, responding to an interview question I posed about his reaction to the Referee:

Working with her was very much like working with an extremely skilled, consistent, thoroughly prepared actor. Clearly, the fact that she never had an "off night," never forgot a line or changed a bit of blocking, was not a matter of skill or choice but one of technology. Nevertheless, I think my instinctive emotional response to it was to feel grateful and appreciative that she was so consistent in her performance. Ironically, I felt like Paula was very much "there for us" as performers and could be trusted to carry her part of the show each night and support us in ours.

Aaron, by contrast, would describe working with Paula's mediated performance very much like working with a very bad actor, one that did not "give you anything." He often felt that Paula was not looking at him when he wanted her to, was not listening to him, and would not react to his attempts to reach out to her emotionally. His process was very different and, in some ways, a lot more technical than Alex's more open and flowing emotional responses.

In Paula's case, her work on that beach in the summer and her disconnection to the final mediation being re-presented in the theatre further informs the discussion. If I had simply told Paula that I was doing a film adaptation of Never Swim Alone and that her scenes were being shot separately from the other actors, she 
could easily make the shift in her technique and presence to that of "film actress." Forcing her, and myself as video director, to reframe the process as one that is in relationship to the live performance happening at an unspecified later date, with unspecified performance partners, makes her performance something as yet undefined: a digitally, technologically embodied experience. Paula felt her goal was to provide the images I wanted to work into the live performance. What I really wanted was a performance that could be reinvested with life by the live actors. For that to happen, I needed to convince those actors that this was possible. I needed them to believe that Paula's performance was somehow mutable, that a conversation would appear possible from the point of view of the audience.

Kuhn suggests exactly this public part of the process, and, I think, an underlying sense of ethics, in stating that these memory texts are "used by their compilers and owners as prompts for performances of memory in private, interactive, collective, and sometimes even public, context." 59 Kuhn's inquiring attitude is perhaps even more significant as it suggests that working on these memories is in itself a process of investigation, and that there is a responsibility to inquire rather than divorce oneself from the mediation of a memory. Taking this to the extreme, crime photographers or the creators of propaganda images are implicated in the process of memory work associated with the experiences and emotional states they are representing. In intermedial metatheatre, that moment of re-construction, of representation happens throughout rehearsal and then in a public context, a context specifically designed to encourage observation and even judgement.

\section{CONCLUSION}

Intermedial theatre lays open these processes of re-construction and representation, creating a site for the social re-creation of memory texts to be staged and witnessed. What is important, is that we do not focus solely on that moment of reengagement; it is but one element of the chain of ethically charged decisions (capturing, cutting, compiling, ordering, performing, witnessing) that lead to the creation of further memories, further mediations, further retentions and performances. This allows us to think temporally about the process of mediating and technologizing memory, and to make connections between the slipperiness of metatheatrical story worlds and stage worlds, of memories that are embodied in performances, both present and absent. We can respond to the lifeness of mediation, 
just as myself, Alex, Aaron, and our audience in the Village Theatre in Hudson, respond to the unique being that is projected into the space during the play. I can choose to confer life on the mediation, just as Alex explained to me in response to a question about what Paula's performance was to him: "I wasn't ever unaware that I was relating to a recorded person. However, I would say that I sort of ascribed a personhood to her, assuming a presence and an awareness that wasn't necessarily there.”

We make a choice to ascribe lifeness to mediated memory, and I argue that such a choice is informed by the liminal nature of the theatrical moment and the unique suspension of time in a metatheatrical work. The work of intermedial metatheatre is to create the circumstances where that kind of choice is not only possible, but is a choice that increases our enjoyment and our investment in the making and receiving of the play. The work is to communicate the possibility of that choice to an audience by allowing them to ascribe their own lifeness to both digitally mediated and live performances in some measure, and in so doing, to invite questions of responsibility and connection to the past, and the potentials in these new forms. It is a function of how we as theatre practitioners and message-makers want to mobilize mediated performances. The implications beyond the theatre abound as we continue to theatricalize our politics and our culture as a whole, both aware and yet enmeshed in a performative interaction with their texts and embodiments in time. Intermedial metatheatre is a means to provoke new understanding of the performativity of media and of the work of capturing, exteriorizing, and re-animating memories before an audience. 


\title{
Making Memories: \\ Time and Responsibility in Intermedial Metatheatre
}

\author{
LOWEll GaSOI, SCHOOL OF JOURNALISM AND COMMUNICATION \\ (CARLETON UNIVERSITY)
}

\section{ABSTRACT}

That performance can be captured and replayed may be a given, but much less wellunderstood is the relationship between that stored performance, the memory of a performed act, and the live event. The practice of intermedial theatre offers a unique way to probe that relationship, and the awareness of metatheatre further exposes the links between memory, technology, and performance. This paper argues that intermedial metatheatre, and my own work as a director, video-maker, and video performer for a 2014 production of Daniel MacIvor's play Never Swim Alone, provides a valuable model for research-creation that can shed light on these questions in an embodied and experiential manner. Engaging with Sarah Kember and Joanna Zylisnka's notion of performative media, as well as the concept of memory work from Annette Kuhn, I offer thoughts on materiality, time, and mediated memory, captured through technologies like camera and sound recording equipment, and in constructed spaces like studios and rehearsal rooms, represented by projection mapping software and digital projectors in the theatre space. All these are integrated into the network of actors and techniques that make up current practices in intermedial theatrical creation. Can this research begin to unravel ideas of authenticity and liveness when reactivating memories in relation to live actors, and before an audience? And what of our responsibility to the digital representation and the live performer when bringing these memories and moments together? How does the network of technologies and practitioners in intermedial theatre creation and presentation, understand and respect the "lifeness" of a mediated memory?

\section{RÉSUMÉ}

Il est peut-être admis qu'une performance peut être captée et rediffusée, mais le rapport existant entre cette performance enregistrée, la mémoire de l'acte performé et l'événement direct est bien moins évident. De même que la pratique d'un théâtre intermédial offre une perspective spécifique sur ce rapport, prendre conscience de la métathéâtralité permet de mettre en évidence les liens existant entre mémoire, technologie et performance. Dans cet article, je soutiens que le métathéâtre intermédial, au même titre que mon propre travail de metteur en scène, vidéaste et performeur vidéo lors de la production en 2014 de Never Swim Alone - une pièce de Daniel MacIvor , est un bon exemple de recherche-création pouvant éclairer ces questions de façon 
concrète et expérientielle. À partir de la notion de média performatif développée par Sarah Kember et Joanna Zylinska et du concept de travail de mémoire pensé par Annette Kuhn, je propose une réflexion sur la matérialité, le temps et la reconstitution médiatique de la mémoire, captés par des technologies telles que les caméras et les équipements de prise de son, et dans des espaces construits comme les studios et les salles de répétition, représentés par des logiciels cartographiant les projections et par des projecteurs numériques installés dans l'espace théâtral. Tous ces éléments sont intégrés à un réseau d'acteurs et de techniques qui rendent compte des pratiques ayant cours dans les créations du théâtre intermédial. Cette recherche est-elle capable d'éclaircir les idées d'authenticité et de liveness quand sont réactivées des mémoires par la présence des acteurs sur scène, et ce, devant une audience ? Et qu'en est-il de notre responsabilité à l'égard de la représentation numérique et des performeurs, lorsque nous réunissons ces mémoires et ces moments? De quelle manière le réseau de technologies et d'agents investis dans la création et la présentation de pièces de théâtre intermédial comprend-il et respecte-t-il la lifeness d'une mémoire reconstituée médiatiquement ?

\section{BIOGRAPHICAL NOTE}

LOWELl Gasol is a 2017 Vanier Canada Scholar and $\mathrm{PhD}$ Candidate in Communication Studies at Carleton University in Ottawa. His research examines the relationship between artists and the Canadian state. He has over 25 years of experience as a theatre-maker and an arts administrator. He holds a BA and an MA in Media Studies from Concordia University. His MA project employed research-creation to explore links between the live and the digitally recorded in intermedial metatheatre. He has been a researcher and consultant with the International Association of Art for Social Change and, currently, with the Canadian Arts Coalition. He thinks, teaches, and writes about performativity, rhetoric, and the continuing relevance of the "live" in communication and media studies.. 